\section{Irrigation Frequency Effects on Turgor Pressure of Creeping Bentgrass and Soil Air Composition}

\author{
John E. Jordan, Richard H. White, James C. Thomas, ${ }^{1}$ Trent C. Hale, \\ and Donald M. Vietor \\ Soil and Crop Sciences Department, Texas A\&M University, College Station, \\ TX 77843-2474
}

Additional index words. Agrostis palustris, plant water relations, osmotic potential, oxygen, carbon dioxide

\begin{abstract}
Proper water management is a major responsibility of managers of creeping bentgrass grown on putting greens in the hot and humid southern states. The combination of shallow root systems, sand-based root zones, high temperatures, and high evaporative demands frequently results in severe drought stress on bentgrass (Agrostis palustris Huds.) greens. This study was initiated to determine the effects of irrigation frequency on creeping bentgrass turgor pressure and on the $\mathrm{O}_{2}$ and $\mathrm{CO}_{2}$ concentrations in a sand-based root zone mixture. In total, 81 plots, $1.5 \times 1.5 \mathrm{~m}$ each, were established on a USGA-type root zone mixture and organized into 9 groups of 9 plots each. Each group could be irrigated individually. One plot in each group was planted to either ' $\mathrm{A}-4$ ', 'Crenshaw', 'Mariner', 'L-93', or 'Penncross' creeping bentgrass. Irrigation frequency treatments of 1-, 2-, and 4day replacement of historical PET were imposed on three groups each. After establishment, measurements of the leaf water potential, osmotic potential, soil oxygen concentration, and soil carbon dioxide concentrations were made over a 1- to 2-year period. Bentgrass irrigated every 1 or 2 days had significantly $(P=0.05)$ greater turgor pressures at $0600 \mathrm{hr}$ as compared to turf irrigated every 4 days in 1997. No differences were seen in 1998 due to drier environmental conditions. Concentrations of $\mathrm{O}_{2}$ and $\mathrm{CO}_{2}$ in the soil air remained in the optimal range for all treatments, indicating that lack of $\mathrm{O}_{2}$ in the root zone as a result of frequent irrigation may not be the primary cause for reduced rooting depth of bentgrass grown on highly permeable sand-based root zone mixtures.
\end{abstract}

Turfgrass growth, health and appearance are greatly affected by its environment. Supraoptimal temperature $\left(35^{\circ} \mathrm{C}\right.$ and above $)$ in the root zone increases root mortality, decreases the number of roots and decreases the nutrient content of the roots and shoots (Dernoeden, 2000; Huang and $\mathrm{Xu}, 2000)$. Much of this response to high temperature in bentgrass is due to increased dark respiration rates at elevated temperatures which increases carbon consumption (Huang and Gao, 2000; Liu and Huang, 2001). When increased respiration is combined with reduced photosynthesis due to low mowing heights and drought stress, the plants frequently experience a net loss of carbon at temperatures of $30{ }^{\circ} \mathrm{C}$ or above. Of these environmental and cultural factors, the one over which turf managers have the most direct control is drought stress.

To reduce the effects of drought stress on turf, most highly managed turf areas are irrigated. Proper irrigation scheduling for optimal turf quality and performance has been the subject of much debate. In general, deep irrigation applied less frequently is preferred as it allows

Received for publication 20 Feb. 2004. Accepted for publication 22 May 2004. We gratefully acknowledge the generous assistance and support from Mark Hall in helping with establishing and managing this study. This research was supported in part by the United States Golf Association and the Texas Turfgrass Association. This work was done in partial fulfillment of a MS degree.

${ }^{1}$ To whom reprint requests should be addressed; e-mail jc-thomas@tamu.edu. inhibits respiration, watc transpiration. In the summertime, the reduced transpiration rate is often accompanied by high temperatures after a storm event, resulting in supraoptimal tissue temperatures, which may further damage or kill the plant (Dernoeden, 2000). Accumulations of organic matter and topdressing sand form what is commonly referred to as a turf mat layer. Such layers typically hold large amounts of water, are poorly aerated, and may also result in wet wilt despite the absence of ponded water on the soil surface (Dernoeden, 2000).

Since leaf expansion ultimately depends on maintaining a positive turgor potential or pressure within the cell (Hsiao, 1973), growth ceases when turgor pressure is lost and the plant wilts (Youngner, 1985). Low $\mathrm{O}_{2}$ concentrations in soil due to saturated soil conditions may result in reduced root and shoot growth, dry matter accumulation and final yield (Drew, 1991, 1997). The threshold $O_{2}$ concentration at which the rate of root extension decreases in rice seedlings was about $0.105 \mathrm{~cm}^{3} \cdot \mathrm{cm}^{-3}$ or half that of air (Turner et al., 1981) but was highly dependent on cultivar.

Holder and Brown (1980) showed a linear relationship between water and oxygen uptake in bean plants (Phaseolus vulgaris L.). Their data showed that $1 \mathrm{~g}$ of $\mathrm{O}_{2}$ was required per $250 \mathrm{~g}$ water taken up by the plant. At $\mathrm{O}_{2}$ concentrations $<0.03 \mathrm{~cm}^{3} \cdot \mathrm{cm}^{-3}$, water uptake was severely reduced and recovery time was delayed when the roots were subjected to prolonged periods of low oxygen.

The exchange of $\mathrm{O}_{2}$ and $\mathrm{CO}_{2}$ between all respiring cells and their immediate environment is dependent upon diffusion (Lemon, 1962). The rate of diffusion of $\mathrm{O}_{2}$ and $\mathrm{CO}_{2}$ through soil has been shown to be affected by soil water content, bulk density, temperature, and root respiration (Beard, 1973; Ouyang and Boersma, 1992). The rate of metabolic $\mathrm{O}_{2}$ uptake by root tissues varies with the genetic background and the physiological age of the tissue (Lemon and Wiegand, 1962). Also, the critical $O_{2}$ concentration at the root surface strongly depends on the root radius and the $\mathrm{O}_{2}$ diffusion coefficient within the root (Lemon and Wiegand, 1962).

Root zone mixtures designed according to the U.S. Golf Association (USGA) method (USGA, 1993) are selected to have high saturated hydraulic conductivities in the range of 15 to 30 $\mathrm{cm} \cdot \mathrm{h}^{-1}$ and a minimum of $0.15 \mathrm{~cm}^{3} \cdot \mathrm{cm}^{-3}$ air-filled pore space after compaction. Thus, the root zone should remain well aerated and contain adequate $\mathrm{O}$ to support root growth and water uptake under all but the very worst situations.

Despite previous research and current recommendations, many golf course superintendents in the southern United States who are growing bentgrass greens on sand-based root zones, feel that they must irrigate the turf on a daily basis to provide adequate soil moisture to prevent drought stress. Therefore, the present study was conducted to determine 1 ) the effects of irrigation frequency on creeping bentgrass turgor pressure and 2) the effects of irrigation frequency on $\mathrm{O}_{2}$ and $\mathrm{CO}_{2}$ concentrations in a USGA-type sand-based root zone mixture.

\section{Materials and Methods}

In total, 81 plots $(1.5 \times 1.5 \mathrm{~m}$ each $)$ were established on a putting green constructed 
Table 1. Particle size distribution and physical properties of the root zone mixture used in this study.

\begin{tabular}{lcc}
\hline & \multicolumn{2}{c}{ Particle size distribution } \\
\cline { 2 - 3 } Fraction & Particle diam $(\mathrm{mm})$ & Amount $\left(\mathrm{g} \cdot \mathrm{g}^{-1}\right)$ \\
\hline Sand & $0.05-2.00$ & 0.987 \\
Silt & $0.002-0.05$ & 0.006 \\
Clay & $<0.002$ & 0.004 \\
Fine gravel & $2.0-4.0$ & 0.003 \\
Very coarse sand & $1.0-2.0$ & 0.02 \\
Coarse sand & $0.50-1.00$ & 0.148 \\
Medium sand & $0.25-0.50$ & 0.515 \\
Fine sand & $0.15-0.25$ & 0.252 \\
Very fine sand & $0.05-0.15$ & 0.052 \\
& & Physical properties \\
Parameter & & Measured value \\
\hline Saturation hydration conductivity & $\mathrm{Units}$ & 41.4 \\
Bulk density & $\mathrm{cm} \cdot \mathrm{h}^{-1}$ & 1.62 \\
Total pore space & $\mathrm{g} \cdot \mathrm{cm}^{-3}$ & 0.380 \\
Capillary pore space & $\mathrm{cm} \cdot \mathrm{cm}^{-3}$ & 0.304 \\
Air-filled pore space & $\mathrm{cm} \cdot \mathrm{cm}^{-3}$ & 0.076 \\
Organic matter content & $\mathrm{cm} \cdot \mathrm{cm}^{-3}$ & 0.019
\end{tabular}

according to the USGA (1993) recommendations. Physical properties of the root zone mixture are shown in Table 1. This root zone mixture is typical of that used for putting green construction in much of the southern U.S. The plots were organized into nine blocks of nine plots each. Each block was equipped with four $90^{\circ}, 3-\mathrm{m}$ stream spray irrigation heads and had independent irrigation control. One plot in each block was planted to one of each of the following five creeping bentgrass cultivars: A-4, Crenshaw, Mariner, L-93, and Penncross. Plots were selected randomly within each block. The remaining four plots in each block, although planted with other cultivars, were not used for this study. A mixture of $2.44 \mathrm{~g} \cdot \mathrm{m}^{-2}$ pure live seed and $2.44 \mathrm{~g} \cdot \mathrm{m}^{-2}$ Milorganite was applied to the selected plots on 19 Nov. 1996. Fertilization, mowing and irrigation were applied uniformly across all plots before the initiation of the irrigation treatments on 21 July 1997. Total $\mathrm{N}$ of $29.3 \mathrm{~g} \cdot \mathrm{m}^{-2} \cdot \mathrm{year}^{-1}$ was applied to all plots. Application rates were $3.27 \mathrm{~g} \cdot \mathrm{m}^{-2}$ every 2 weeks during October to December and 1.22 $\mathrm{g} \cdot \mathrm{m}^{-2}$ every 2 weeks during March to June. Elite polymer-sulfur coated urea (21-4-11 from Lesco Inc., Strongsville, Ohio) was the $\mathrm{N}$ source. Potassium was applied at rates equal to $\mathrm{N}$ by supplementing with a slow release potassium source. Turf quality at the time the treatments began was rated as excellent for putting green use and the stand was considered to be a mature turf. Mowing was done $6 \mathrm{~d} \cdot \mathrm{wk}^{-1}$ at a height of $4 \mathrm{~mm}$.

Irrigation treatments were imposed during the following two periods: 21 July to 4 Sept. 1997 and 22 June to 1 Sept. 1998. Treatments consisted of replacing the full amount of historical potential evapotranspiration (PET) (Dugas and Ainsworth, 1983) from the previous 1-, 2-, or 4-d intervals. For example, a typical irrigation schedule for an 8-d period in August would involve irrigating $7.5 \mathrm{~mm}$ each day for the 1-d treatment, $15 \mathrm{~mm}$ on days 2,4 , 6 , and 8 for the 2 -d treatment, and $30 \mathrm{~mm}$ on days 4 and 8 for the 4 -d treatment. Irrigation treatments (blocks) were replicated three times for all five cultivars. Care was taken to ensure that all plots received the same total amount of irrigation water and only differed in the time interval between applications. Irrigation was conducted between 0100 to $0600 \mathrm{HR}$ and was limited to periods when the wind velocity was $2 \mathrm{~m} \cdot \mathrm{s}^{-1}$ or less to assure uniformity. Collection gauges were used to monitor irrigation uniformity of all treatments. Irrigation uniformity was $82 \%, 83 \%$, and $83 \%$ for the 1-, 2-, and 4-d irrigation blocks respectively (Jordan et al., 2003). During the fall, winter, and spring seasons when irrigation treatments were not imposed, maintenance irrigation was done twice per week in amounts equal to Class $\mathrm{A}$ pan evaporation.

Weather data were collected by an automated weather station (Campbell Scientific) located within $100 \mathrm{~m}$ of the experimental site. Measurements included minimum and maximum air temperatures, relative humidity, wind speed, pan evaporation and precipitation. Pan evaporation was measured manually using a Class A evaporation pan (Bloodgood et al., 1954) and a hook gauge.

Concentrations of $\mathrm{CO}_{2}$ and $\mathrm{O}_{2}$ in the soil air were measured for two 5 -d periods starting on 10 and 26 Aug. 1998 using a multi-gas analyzer (model 18103614-1414; Industrial Scientific, Oakdale, Pa.). A 2-cm-diameter soil probe was manually inserted to a depth of $12 \mathrm{~cm}$ and the soil core was removed. The gas analyzer probe was then inserted to a depth of about $10 \mathrm{~cm}$ into the aerification hole and measurements were taken until a steady reading was obtained, which typically took 1 to $2 \mathrm{~min}$. The gas probe was tapered (wider at upper end) so that the upper end acted as a stopper to minimize air entry into the hole while measurements were being taken. Except for the time while measurements were being taken, all holes were sealed with corks.

Leaf water potential was determined using precalibrated thermocouple psychrometers (model 84-1VC; J.R.D. Merrill Specialty Equipment Corp., Logan, Utah) following the basic procedures of Qian and Fry (1996). Following each sample collection event the psychrometers were placed in a $20{ }^{\circ} \mathrm{C}( \pm 0.1$ ${ }^{\circ} \mathrm{C}$ ) water bath for a 2 HR equilibration period before measurement of the leaf water potential. Following equilibration, microvolt readings from the psychrometers were collected using a datalogger (modelCR7; Campbell Scientific, Logan, Utah) programmed to apply a 5-s cooling current, and then record the internal chamber temperature, microvolt offset, and microvolt output $6 \mathrm{~s}$ after the end of the cooling current application. Measurements of each psychrometer were repeated at 15-min intervals. Three consecutive measurements for each sample were averaged for use in calculating the leaf water potential. Immediately following measurement of the leaf water potential, the psychrometer chambers were placed in $\mathrm{a}-20{ }^{\circ} \mathrm{C}$ freezer for a minimum of $12 \mathrm{~h}$ and then returned to the $20{ }^{\circ} \mathrm{C}$ water bath to thaw and equilibrate to the water temperature. The leaf osmotic potential was then measured as described above for the leaf water potential. Turgor pressure was calculated by subtracting the leaf osmotic potential from the leaf water potential.

Sampling of leaf tissue for determination of the baseline leaf water potential was done at $0600 \mathrm{HR}$ to minimize variability due to environmental changes. Sampling dates were 28 July 1997, 6 Aug. 1997, 20 Aug. 1997, 8 July 1998, 9 July 1998, and 24 July 1998. Except for the 9 July 1998 date, all samples were taken the morning before irrigation and represent plants growing under the lowest soil moisture contents experienced in each irrigation treatment. In contrast, the 9 July, 1998 sample was taken the morning after irrigation and is representative of plants growing under highest soil moisture conditions in each given treatment. Two to five leaf blades were excised at the collar and were placed into the psychrometer within $5 \mathrm{~s}$. All psychrometers were kept in an insulated ice chest to minimize temperature fluctuations during the sample collection period. The same procedure was also used to collect tissue samples at $1400 \mathrm{hrs}$ for measurement of leaf water potential during periods of high evaporative demand.

Diurnal measurements of leaf water potential were also made on 6 selected dates each year by collecting samples as described above from each of the irrigation treatments at 0600, 0900, 1200, 1500, and 1800 HR. Three sample dates each year were selected to be the day preceding irrigation of both the 2- and 4-d treatments and represent plants growing under the lowest soil moisture contents experienced in each irrigation treatment. The remaining three dates each year were selected to be the day immediately following irrigation of all treatments and represent plants growing under highest soil moisture conditions in each treatment. Data from 1997 and 1998 were pooled due to similar trends in the data.

All data were statistically evaluated using Analysis of variance (AOV) for a split plot design. Each years data were analyzed separately to remove any effects of year. When AOV indicated significant differences, the means were separated by using the StudentNewman-Keuls Method (Zar, 1996).

\section{Results and Discussion}

Weather and soil conditions. The weather conditions at the experimental site during the 
Table 2. Weather conditions at the experimental site during May - August of 1997 and 1998.

\begin{tabular}{lccrc}
\hline Mean avg & $\begin{array}{c}\text { Mean } \\
\text { air temp } \\
\left({ }^{\circ} \mathrm{C}\right)\end{array}$ & $\begin{array}{c}\text { Welative } \\
\text { humidity } \\
(\%)\end{array}$ & $\begin{array}{c}\text { Wind } \\
\text { speed } \\
\left(\mathrm{m} \mathrm{s}^{-1}\right)\end{array}$ & $\begin{array}{c}\text { Total } \\
\text { precipitation } \\
(\mathrm{mm})\end{array}$ \\
\hline 1997 & 22.8 & 77.0 & 2.8 & 53.6 \\
May & 26.2 & 76.1 & 2.0 & 140.2 \\
June & 29.4 & 69.0 & 2.1 & 41.9 \\
July & 28.9 & 68.2 & 2.4 & 20.1 \\
August & & & & 255.8 \\
Total & & & 2.3 & 4.1 \\
1998 & 26.0 & 70.9 & 3.1 & 5.6 \\
May & 29.5 & 68.5 & 3.2 & 21.1 \\
June & 30.5 & 65.4 & 2.2 & 79.3 \\
July & 30.0 & 70.6 & & 110.1 \\
August & & & & \\
Total & & & & \\
\hline
\end{tabular}

Table 3. Turgor pressure of creeping bentgrass cultivars at 0600 and $1400 \mathrm{HR}$ in July and August 1997 and 1998.

\begin{tabular}{lllllll}
\hline & \multicolumn{5}{c}{ Turgor pressure (MPa) } \\
\cline { 2 - 4 } Cultivar & 1-Day & 2-Day & 4-Day & 1-Day & 2-Day & 4-Day \\
\cline { 2 - 5 } 0600 HR & & & & \\
A-4 & $1.44 \mathrm{a}^{\mathrm{y}}$ & $0.88 \mathrm{c}$ & $0.33 \mathrm{~b}$ & $0.45 \mathrm{a}$ & $0.48 \mathrm{a}$ & $0.41 \mathrm{a}$ \\
Crenshaw & $1.39 \mathrm{a}$ & $1.27 \mathrm{bc}$ & $0.33 \mathrm{~b}$ & $0.58 \mathrm{a}$ & $0.36 \mathrm{a}$ & $0.42 \mathrm{a}$ \\
L-93 & $1.35 \mathrm{a}$ & $1.88 \mathrm{a}$ & $0.52 \mathrm{ab}$ & $0.47 \mathrm{a}$ & $0.39 \mathrm{a}$ & $0.42 \mathrm{a}$ \\
Mariner & $1.66 \mathrm{a}$ & $1.10 \mathrm{bc}$ & $0.65 \mathrm{a}$ & $0.40 \mathrm{a}$ & $0.39 \mathrm{a}$ & $0.50 \mathrm{a}$ \\
Penncross & $1.03 \mathrm{a}$ & $1.34 \mathrm{~b}$ & $0.40 \mathrm{ab}$ & $0.56 \mathrm{a}$ & $0.38 \mathrm{a}$ & $0.43 \mathrm{a}$ \\
Mean & $1.37 \mathrm{a}$ & $1.29 \mathrm{a}$ & $0.45 \mathrm{~b}$ & $0.49 \mathrm{a}$ & $0.40 \mathrm{~b}$ & $0.44 \mathrm{ab}$ \\
1400 HR & & & & & & $0.30 \mathrm{a}$ \\
A-4 & $0.53 \mathrm{a}$ & $0.29 \mathrm{a}$ & $0.06 \mathrm{~b}$ & $0.28 \mathrm{a}$ & $0.29 \mathrm{a}$ & $0.19 \mathrm{a}$ \\
Crenshaw & $0.63 \mathrm{a}$ & $0.56 \mathrm{a}$ & $0.20 \mathrm{~b}$ & $0.28 \mathrm{a}$ & $0.15 \mathrm{a}$ & $0.28 \mathrm{a}$ \\
L-93 & $0.25 \mathrm{a}$ & $0.35 \mathrm{a}$ & $0.19 \mathrm{~b}$ & $0.27 \mathrm{a}$ & $0.13 \mathrm{a}$ & $0.30 \mathrm{a}$ \\
Mariner & $0.53 \mathrm{a}$ & $0.36 \mathrm{a}$ & $0.48 \mathrm{a}$ & $0.27 \mathrm{a}$ & $0.29 \mathrm{a}$ & $0.35 \mathrm{a}$ \\
Penncross & $0.44 \mathrm{a}$ & $0.32 \mathrm{a}$ & $0.19 \mathrm{~b}$ & $0.37 \mathrm{a}$ & $0.23 \mathrm{a}$ & $0.35 \mathrm{a}$ \\
Mean & $0.48 \mathrm{a}$ & $0.38 \mathrm{a}$ & $0.22 \mathrm{~b}$ & $0.29 \mathrm{a}$ & $0.22 \mathrm{a}$ & $0.28 \mathrm{a}$ \\
\hline
\end{tabular}

${ }^{2}$ Values in a given column for a given sampling time followed by the same letter do not differ significantly at $P=0.05$.

${ }^{y}$ Values are the means of measurements taken on three dates each year.

${ }^{\mathrm{x}}$ Means for irrigation intervals in a given row for a given time and year followed by the same letter do not differ significantly at $P=0.05$.

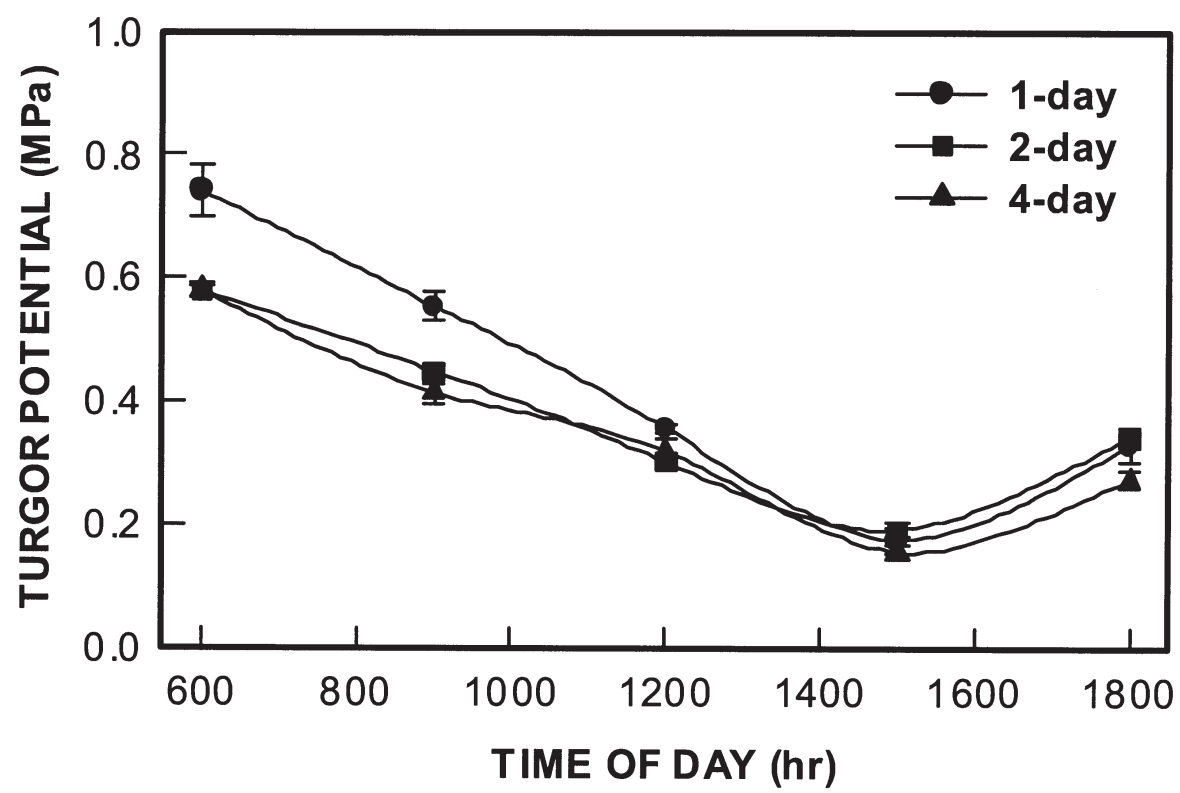

Fig. 1. Turgor pressure as a function of time of day for three irrigation frequencies. Measurements were taken on the day before irrigation of all treatments. Data points are the mean of six sampling dates (three each in 1997 and 1998).

summer periods when irrigation treatments were applied are summarized in Table 2. Comparison of the data for the summers of
1997 and 1998 show that during the summer of 1998 the environmental conditions were warmer, windier, and drier.
Under the conditions of this experiment, daily irrigation of the turf in amounts equal to the historical PET did not result in saturated or anaerobic soil conditions. The high sand content root zone mixture was typical of many USGA type greens and had a high permeability to water and air. Since the experimental putting green was new, it had $<6 \mathrm{~mm}$ of thatch or turf mat which did not interfere with moisture and air movement.

Turgor pressure. Within the 1-d irrigation frequency treatment at 0600 and $1400 \mathrm{HR}$, and the 2-d irrigation treatment at $1400 \mathrm{HR}$ for 1997 , no significant differences $(P=0.05)$ in turgor pressure were observed among cultivars (Table 3). For the 2-d irrigation treatment at $0600 \mathrm{HR}$, 'L-93' had significantly greater turgor pressure. 'Mariner' had the greatest turgor pressure in 1997 at $1400 \mathrm{HR}$ in the 4-d irrigation treatment. However, at $0600 \mathrm{HR}$ 'Mariner' had greater turgor pressure than 'A-4' and 'Crenshaw' but did not differ from 'L-93' or 'Penncross'. During the 1998 season, no significant differences in turgor pressure were observed between the cultivars at either 0600 or 1400 HR.

When averaged over all cultivars, plants in the 1- and 2-d irrigation frequency treatments had significantly $(P=0.05)$ greater turgor pressures compared to those in the 4-d irrigation frequency treatment during 1997. At $0600 \mathrm{HR}$ the 1-d treatment had $0.92 \mathrm{MPa}$ greater turgor pressure than the 4-d treatment, but by $1400 \mathrm{HR}$ the difference decreased to $0.26 \mathrm{MPa}$ due to the greater evaporative demand during midday (Table 3). During the 1998 season, the turgor pressures were much lower and remained at $<0.6 \mathrm{MPa}$. Differences due to irrigation frequency in 1998 were not significant due to the greater evaporative demand that resulted from higher air temperatures, greater wind speeds, and the lower amount of precipitation (Table 2). These factors combined in 1998 to maintain a nearly constant evaporative demand and effectively prevented the turf from achieving the high turgor pressure that was achieved for the 0600 HR measurements for the 1- and 2-d treatments in 1997.

Immediately before irrigation, when the plants were experiencing the lowest soil moisture contents in their respective irrigation treatments, significant differences $(P=0.05)$ existed between the turgor pressure of plants in the 1-d irrigation treatment and those from the 2- and 4-d treatments at 0600 and $0900 \mathrm{HR}$ (Fig. 1). As the time approached $1200 \mathrm{HR}$, the turgor pressures of the treatments converged and no significant differences were observed for measurements taken at 1200 and 1500 HR. By 1800 HR the turgor pressure of the 4-d treatment was beginning to diverge from the other treatments. Diurnal patterns immediately after irrigation were much different. Turgor pressures of bentgrass receiving the 2 - and 4-d treatments were significantly $(P=0.05)$ less than those of the 1-d treatment at 0600 and $0900 \mathrm{HR}$ (Fig 2). By $1200 \mathrm{HR}$, the turgor pressures for all three treatments were nearly equal. The delay in turgor pressure recovery to prestress levels may be due to one of several factors. First, it may be a response to the lower oxygen and higher $\mathrm{CO}_{2}$ concentrations 


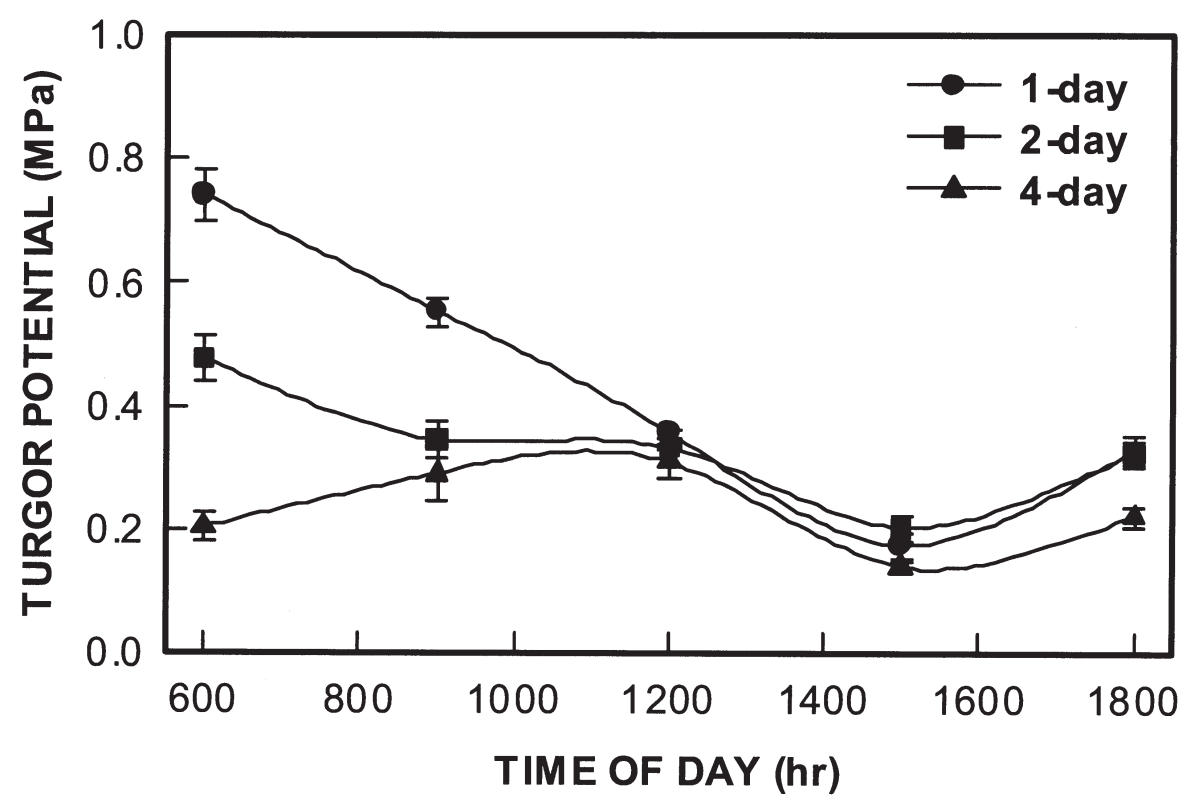

Fig. 2. Turgor pressure as a function of time of day for three irrigation frequencies. Measurements were taken on the day following irrigation of all treatments. Data points are the mean of six sampling dates (three each in 1997 and 1998).

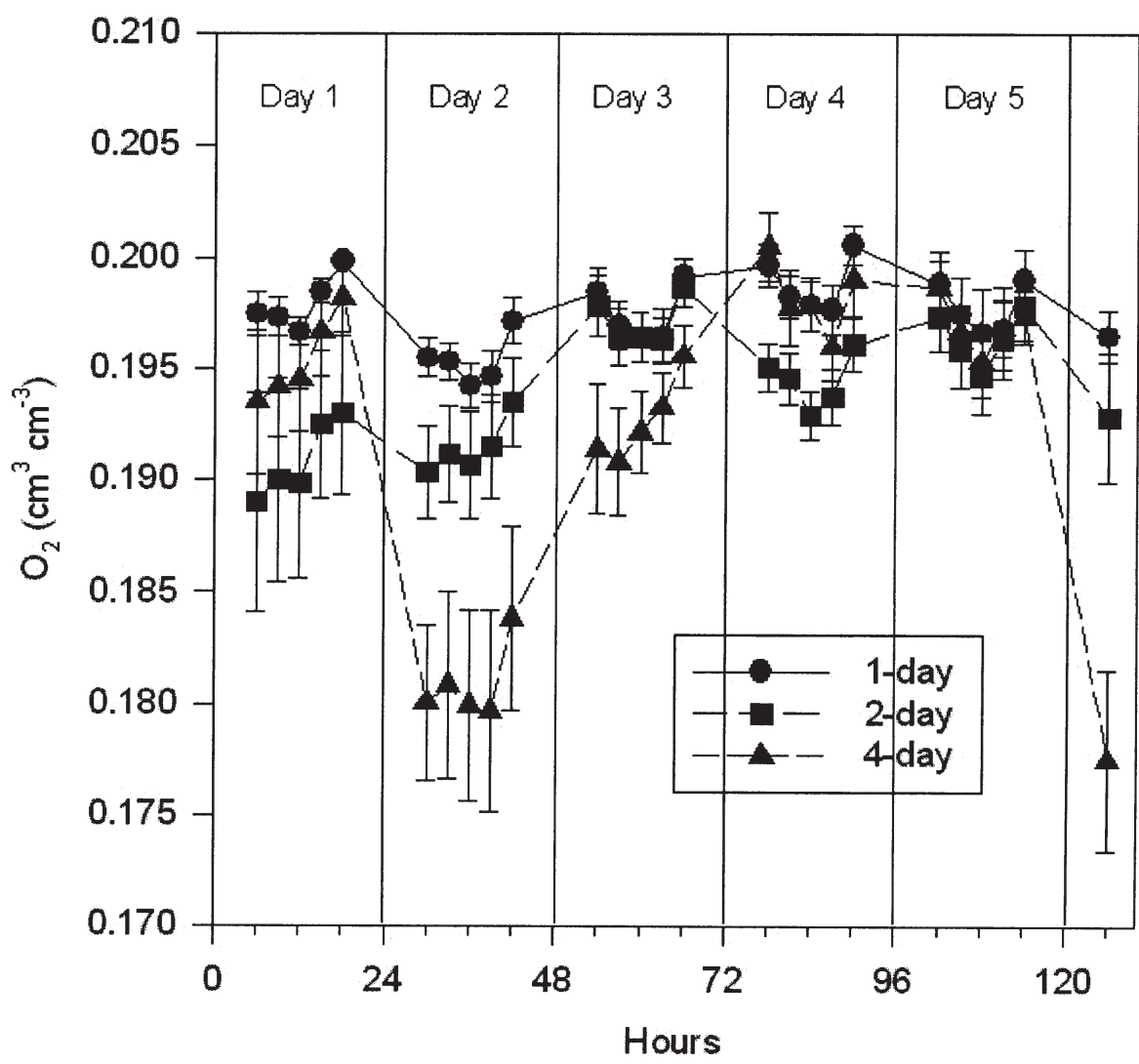

Fig. 3. Oxygen concentrations in the soil air $12 \mathrm{~cm}$ below the soil surface over a 5-d period in 1998 as affected by three irrigation frequencies. The 1-d treatment was irrigated at 26, 50, 74, 98, and $122 \mathrm{~h}$. The 2-d treatment was irrigated at 26, 74, and $122 \mathrm{~h}$ and the 4-d treatment was irrigated at 26 and $122 \mathrm{~h}$.

in the soil air as documented in the following sections. Secondly, it may be related to the greater root density of preconditioned plants (Jordan et al., 2003). More roots in the same volume of soil results in increased respiration, increased $\mathrm{CO}_{2}$ concentrations and decreased $\mathrm{O}_{2}$ concentrations. Finally, plants exposed to drought stress may undergo some aging of the roots and associated reduction of root permeability (Alam, 1994; Drew, 1967).

Turf quality. Turf quality during 1997 was low due to the frequent rains and high humidity (Jordan et al., 2003). Turf quality during 1998 was much improved and remained well within the acceptable range. However, there was no significant difference due to irrigation treatment except for the last two measurements of 1998 which indicate that turf quality of the 4-d treatment was superior to that of the 1-d and 2-d treatments. This is likely due to the preconditioning effect (Huang and Jiang, 2002; Qian and Fry, 1996) which allowed plants in the 4-d treatment to continue growth to lower water potentials.

Soil air. Oxygen concentrations for the 1 -d irrigation treatment were slightly $<0.20$ $\mathrm{cm}^{3} \cdot \mathrm{cm}^{-3}$ and remained nearly constant over the 5-d measurement period (Fig. 3). Oxygen concentrations in the 2-d treatment decreased about $0.005 \mathrm{~cm}^{3} \cdot \mathrm{cm}^{-3}$ for $1 \mathrm{~d}$ after irrigation and then increased to those of the 1 -d treatment. The 4-d irrigation treatment showed a much larger decrease of $0.02 \mathrm{~cm}^{3} \cdot \mathrm{cm}^{-3}$ for a full day and required $2 \mathrm{~d}$ to return to oxygen levels similar to those of the 1-d treatment. This difference is likely to be due to the greater root length density of the 4-d treatment (Jordan et al., 2003) which allowed greater $\mathrm{O}_{2}$ consumption at the $12 \mathrm{~cm}$ depth as compared to the more shallow rooted turf in the 1- and 2-d irrigation frequency treatments.

Carbon dioxide concentrations in the soil air showed a diurnal pattern for all irrigation treatments (Fig. 4). Carbon dioxide concentrations were greatest at the $0600 \mathrm{HR}$ measurement and progressively decreased throughout the day to a low at $1500 \mathrm{HR}$. Generally, there was a slight increase in carbon dioxide concentration at $1800 \mathrm{HR}$ and a much larger increase by $0600 \mathrm{HR}$ on the following morning. This behavior is likely due to decreased availability of photoassimilates for root respiration during the day. Products of photosynthesis are stored as starches in the leaf cells during the day. At night, conversion of the starches to sugars allows their translocation from the leaf to the roots (Geiger et al., 2000) resulting in greater rates of root respiration which increased the $\mathrm{CO}_{2}$ levels in the soil air.

Carbon dioxide concentrations in the 2-d irrigation treatment increased about 0.003 $\mathrm{cm}^{3} \cdot \mathrm{cm}^{-3}$ after irrigation and required 1 to 2 $\mathrm{d}$ to return to the levels in the 1-d irrigation treatment. Concentrations in the 4-d treatment increased nearly $0.01 \mathrm{~cm}^{3} \cdot \mathrm{cm}^{-3}$ after irrigation and required a full $2 \mathrm{~d}$ to return to the levels in the 1-d irrigation treatment. The greater response of the 4-d irrigation treatment may be due in large part to the greater root length density at the $12 \mathrm{~cm}$ depth of this treatment (Jordan et.al., 2003) which allowed greater respiration.

\section{Conclusions}

The results of this study indicated that creeping bentgrass turgor pressure is influenced by irrigation frequency. Although infrequent (every $4 \mathrm{~d}$ ) irrigation resulted in lower turgor pressure than frequent $(1 \mathrm{~d})$ irrigation, turf quality of the infrequently irrigated bentgrass did not decline. The assumption that frequent irrigation limits the soil $\mathrm{O}_{2}$ concentration in a well-drained golf green was not supported by this study. Instead, soil $\mathrm{O}_{2}$ concentrations 


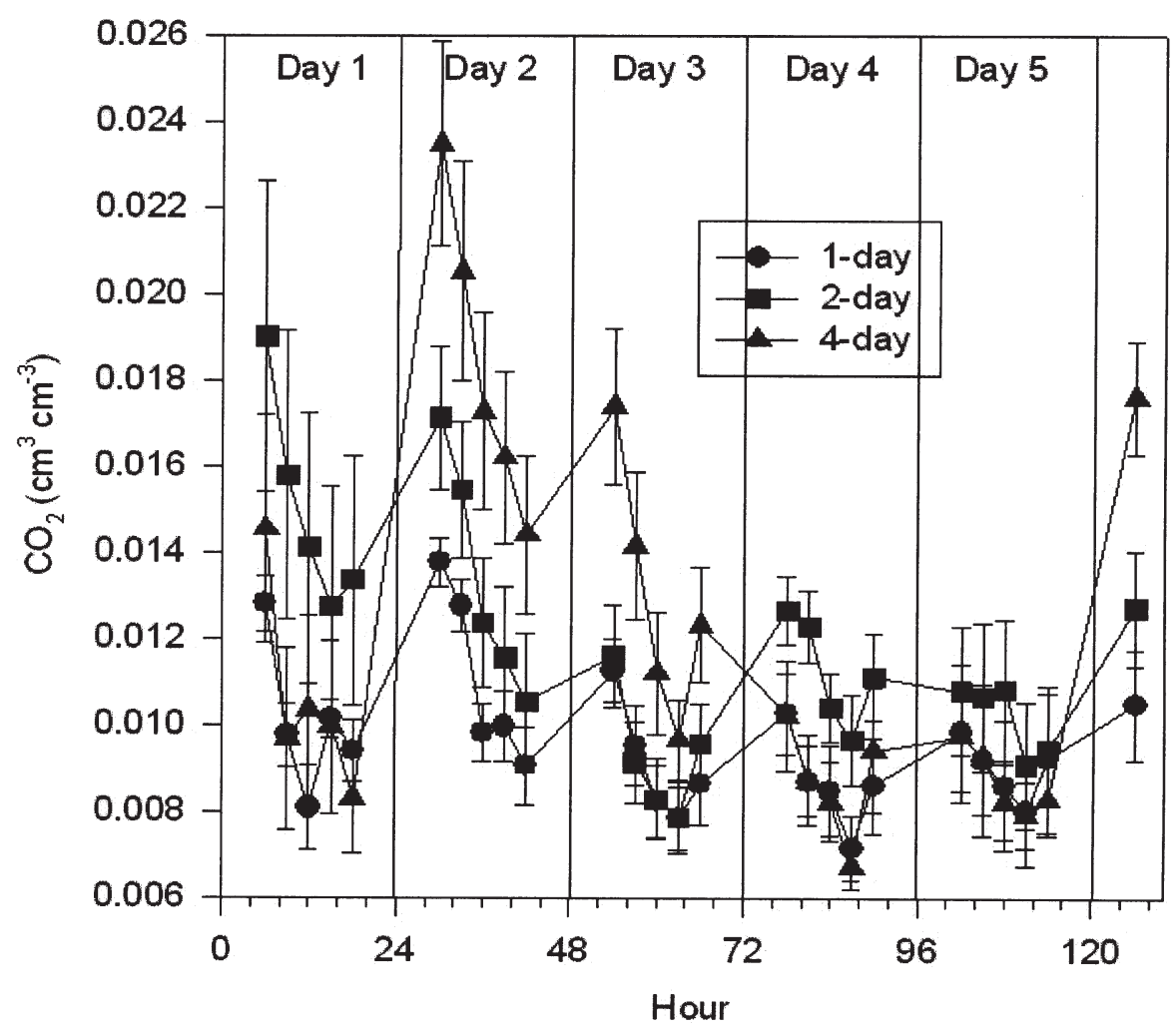

Fig. 4. Carbon dioxide concentrations in the soil air $12 \mathrm{~cm}$ below the soil surface over a 5 -d period in 1998 as affected by three irrigation frequencies. The 1 -d treatment was irrigated at 26, 50, 74, 98, and $122 \mathrm{~h}$. The 2-d treatment was irrigated at 26, 74, and $122 \mathrm{~h}$, and the 4-d treatment was irrigated at 26 and $122 \mathrm{~h}$.

were greater and $\mathrm{CO}_{2}$ concentrations were less when frequent irrigation was applied. These data and those from a companion study (Jordan et al., 2003) suggested that soil $\mathrm{O}_{2}$ availability did not limit root development on frequently irrigated creeping bentgrass grown on a highly permeable sand-based root zone mixture.

\section{Literature Cited}

Alam, S.M. 1994. Nutrient Uptake by Plants Under Stress Conditions, p. 227-246. In: M. Pessarakli (ed.). Handbook of plant and crop stress. Marcel Dekkar, Inc., New York.

Beard, J.B. 1973. Water, p. 261-312. In: Turfgrass science and culture. Prentice-Hall, Englewood Cliffs, N.J.

Bloodgood, D.W., R.E. Patterson, and R.L. Smith, Jr. 1954. Water evaporation studies in Texas. Texas Agr. Expt. Sta.-Texas Agr. Ext. Serv.-Texas Board of Water Eng.-U.S. Dept. Agr. Bul. 787.

Dernoeden, P.H. 2000. Creeping bentgrass management: Summer stresses, weeds, and selected maladies. Ann Arbor Press, Chelsea, Mich.
Drew, D.H. 1967. Mineral nutrition and the water relations of plants. II. Some relationships between mineral nutrition, root function and transpiration rate. Plant and Soil 26:469-480.

Drew, M.C. 1991. Oxygen deficiency in the root environment and plant mineral nutrition, $\mathrm{p}$. 303-316. In: M.B. Jackson et al. (eds.). Plant life under oxygen deprivation. The Netherlands Acad. Publ., The Hague.

Drew, M.C. 1997. Oxygen deficiency and root metabolism: Injury and acclimation under hypoxia and anoxia. Annu. Rev. Plant Physiol. Plant Mol. Biol. 48:223-250.

Dugas, W.A. and C.G. Ainsworth. 1983. Agroclimatic atlas of Texas. part 6. Potential evapotrans-

Ervin, E.H. and A.J. Koski. 1998. Drought avoidbluegrass and tall fescue turfs in the semiarid west. Crop Sci. 38:788-795.

Geiger, D.R., J.C. Servaites and M.A. Fuchs. 2000. Role of starch in carbon translocation and partitioning at the plant level. Austral. J. Plant Physiol. 27:571-582.

Holder, C.B. and K.W. Brown. 1980. The relationpiration. Texas Agr. Expt. Sta. MP-1543. ance aspects and crop coefficients of kentucky ship between oxygen and water uptake by roots of intact bean plants. Soil Sci. Soc. Amer. J. 44:21-25.

Hsiao, T.C. 1973. Plant responses to water stress. Annu. Rev. Plant Physiol. 24:519-570.

Huang, B. and H. Gao. 2000. Growth and carbohydrate metabolism of creeping bentgrass cultivars in response to increasing temperatures. Crop Sci. 40:1115-1120.

Huang, B. and Y. Jiang. 2002. Irrigation management and heat tolerance. Golf Course Mgt. 70:49-52

Huang, B. and Q. Xu, 2000. Root growth and nutrient element status of creeping bentgrass cultivars differing in heat tolerance as influenced by supraoptimal shoot and root temperatures. J. Plant Nutr. 23:979-990.

Johnson, P.G. 2003. The influence of frequent or infrequent irrigation on turfgrasses in the cool-arid west. USGA Turfgrass Environ. Res. Online 2:1-8.

Jordan, J.E., R.H. White, D.M. Vietor, T.C. Hale, and J.C. Thomas. 2003. Effect of irrigation frequency on turf quality, shoot density, and root length density of five bentgrass (Agrostis palustris) cultivars. Crop Sci. 43:282-287.

Lemon, E.R. 1962. Soil aeration and plant root relations. I. Theory. Agron. J. 54:167-170.

Lemon, E.R. and C.L. Wiegand. 1962. Soil aeration and plant root relations. II. Root respiration. Agron. J. 54:171-175.

Liu, X. and B. Huang. 2001. Seasonal changes and cultivar difference in turf quality, photosynthesis, and respiration of creeping bentgrass. HortScience 36:1131-1135.

Madison, J.H. and R.M. Hagan. 1962. Extraction of soil moisture by 'Merion' bluegrass (Poa pratensis $\mathrm{L}$. 'Merion') turf, as affected by irrigation frequency, mowing height and other cultural operations. Agron. J. 54:157-160.

Ouyang, Y. and L. Boersma. 1992. Dynamic oxygen and carbon dioxide exchange between soil and atmosphere: II. Model simulations. Soil Sci. Soc. Amer. J. 56:1702-1710.

Qian, Y.L. and J.D. Fry. 1996. Irrigation frequency affects zoysiagrass rooting and plant water status. Hort. Sci. 31:234-237.

Turner, F.T., C.C. Chen, and G.N. McCauley. 1981. Morphological development of rice seedlings in water at controlled oxygen levels. Agron. J. 73:566-570.

United States Golf Association. 1993. USGA recommendations for a method of putting green construction. USGA Green Section Record (March-April):1-3.

Youngner, V.B. 1985. Physiology of water use, water stress, p. 37-43. In: V.A. Gibeault and S.T. Cockerham (eds.). Turfgrass water conservation. Univ. Calif., Riverside, Coop. Ext. Publ. 21405.

Zar, J. H. 1996. Biostatistical analysis, p. 197-269. Prentice Hall, Upper Saddle River, N.J. 